\title{
ECONOMICS AND ENTERPRISE MANAGEMENT
}

\author{
ЕКОНОМІКА ТА УПРАВЛІННЯ \\ ПІДПРИЕМСТВОМ
}

\section{УДК 330.322.4 \\ КОНЦЕПЦІЯ ПОБУДОВИ ЕФЕКТИВНОЇ БІЗНЕС-МОДЕЛІ ФРАНЧАЙЗИНГУ}

\author{
Наталія Кравчук; Ольга Білоус; Надія Синькевич
}

Тернопільський начіональний технічний університет імені Івана Пулюя, Тернопіль, Україна

\begin{abstract}
Резюме. Досліджено значення франчайзингу на світовому і вітчизняному ринках. Відображено найпопулярніші сегменти франчайзингового ринку в світі та Україні. Розкрито необхідність побудови ефективної бізнес-моделі франчайзингу. Досліджено нормативно-правове забезпечення франчайзингу в Європі та Північній Америці, показано порядок надання інформачії про зміст бізнесу по франшизі, розкриття показників фінансової звітності за рік, відображення змін у фінансовому стані фрачайзера та усі фінансові зобов'язання франчайзі з метою захисту інтересів останнього. Надано порівняльну характеристику та критичну оиінку нормативно-правового регулювання франчайзингу в Украӥні. Відображено переваги та недоліки франчайзингових систем для франчайзера й франчайзі. Розкрито основні етапи розроблення та впровадження ефективної франчайзингової моделі. Показано базові критерії для інтеграиії та розиирення бізнесу у формі франчайзингу. Розкрито, як обрати свій бізнесформат у частині організації та базового проекту бізнесу, реклами, навчання персоналу, організації виробництва, збуту, доставки продукиії. Доведено необхідність упровадження процесу контролю системи франчайзингу на основі базового об'єкта франчайзера, у ході якого підраховують суми фінансових витрат на відкриття бізнесу по франшизі, здійснюється відпрацюювання технологічних чи виробничих стандартів, правил обслуговування, адміністрування, організаџія бізнесу, маркетингова політика, логістика, система обліку та оподаткування, система контролю за франчайзі. Аргументовано, щзо франчайзі також повинен оцінити свої можливості, зрозуміти, щьо таке франчайзинговий бізнес $i$ визначити готовність фінансування франчайзингового бізнесу в потрібному обсязі.
\end{abstract}

Ключові слова: бізнес-модель, франчайзингова система, франчайзер, франчайзі, договір комериійної концесії.

https://doi.org/10.33108/galicianvisnyk_tntu2019.05.040

Отримано 09.10.2019

\section{UDC 330.322.4}

\section{CONCEPT OF EFFECTIVE FRANCHISE BUSINESS MODEL DEVELOPMENT}

\section{Nataliia Kravchuk; Olha Bilous; Nadiya Synkevych}

\section{Ternopil Ivan Puluj National Technical University, Ternopil, Ukraine}

Summary. The importance of franchise in the world and domestic market is investigated in this paper. The most popular franchise market segments in the world and Ukraine are shown. The need for effective franchise 
business model construction is revealed. The legal framework for franchising in Europe and North America has been investigated and the procedure for providing information on the content of the franchise business, business reporting per year, reflecting changes in the financial franchiser state and all financial franchisee liabilities aimed at protection of interests for the latter are shown. The comparative description and critical assessment of the legal franchise regulation in Ukraine is given. Advantages and disadvantages of franchising systems for franchiser and franchisee are presented. The main stages of the development and implementation of effective franchise model are revealed. Basic criteria for franchising business integration and business expansion are outlined. It is explained how to choose your business format in terms of organization and basic project of business, advertising, personnel training, organization of production, sales, delivery of products. The need to introduce the process of franchising system control based on the basic franchiser object in course of which the amounts of financial expenses for opening the franchise business are calculated, the technological or production standards, service rules, administration, business organization, marketing policy, logistics, accounting system and taxation, the franchisee control system are proved. It is well-reasoned that the franchisee must also evaluate their capabilities, understand what franchise business is and specify status to finance franchise business in the required amount.

Key words: business model, franchise system, franchisee, franchiser, franchise agreement.

Постановка проблеми. Приблизно 40\% усіх продажів у світі здійснюється через систему франчайзингу, ця модель успішно використовується в 80 країнах світу. Україна $\epsilon$ перспективним ринком для розвитку бізнесу, особливо у сфері послуг. Зростання розвитку ринку франчайзингу у світі та Україні відкриває нові можливості для внутрішніх та іноземних інвесторів, які хочуть розпочати свою справу, не маючи жодного підприємницького досвіду 3 мінімальним ризиком банкрутства, а також власників малого та середнього бізнесу закріпитися на ринку та примножити свій капітал. Власник будь-якого успішного бізнесу рано чи пізно поставить собі за мету розширитись або ж освоїти нові ринки збуту. Якщо бізнес-модель функціонування підприємства відточена до найменших дрібниць та воно ефективно функціонує, тоді можна розвивати бізнес по франшизі.

У цілому за п'ять років вітчизняний франчайзинговий ринок зріс на третину й сегментований на три сектори. Найпопулярнішими є франшизи в закладах громадського харчування, у сфері послуг та розваг. Водночас терміни «франшиза» та «франчайзинг» застосовується в Україні не так часто, як в Свропі чи США, що зумовлено як об'єктивними, так і суб'єктивними причинами. Приблизно 56\% вітчизняного ринку - це українські франшизи у сфері виробництва, іноземні ж власники франшизи переважають лише на товарному ринку. Такий факт зумовлений тим, що робота переважної більшості міжнародних брендів базується на чіткій бізнес-моделі франчайзингу, якої в Україні, на жаль, ще несформовано.

Аналіз останніх досліджень і публікацій. Значний внесок у дослідження проблем побудови та впровадження ефективного механізму системи франчайзингових відносин здійснили такі вітчизняні та зарубіжні вчені, як Г. Андрощук, В. Денисюк, Ф. Бутинець, А. Виноградська, Р. Кац, Л. Каракашева, Ю. Узунова, Л. Пиперкова, Ж. Дельтей, Д. Аакер, С. Спінеллі, Д. Стенворд, Я. Лісун, Т. Ковальчук, О. Корольчук, О. Кузьміна, В. Мавріду, М. Мендельсон, Т. Мирончук, Я. Мюрей, І. Рикова, О. Сабліна, С. Сілінг, С. Сосна, С. Спінеллі, Д. Стенворт, Б. Сміт, А. Цират, В. Колот, І. Рєпіна, В. Качалін, Р. Кац, В. Колєсніков, О. Щербіна, С. Сосна, Є. Васильєва, Ф. Філіна, Є. Кузьмін, Т. Мирончук, І. Салата, Л. Марчук, ін.

Метою дослідження $є$ комплексний аналіз системи нормативно-правового регулювання, вивчення тенденцій, розроблення та впровадження ефективної бізнесмоделі франчайзингу в Україні як основної форми підприємницької активності, що надасть можливість якісно, швидко та 3 вигодою для себе вибудувати власний прибутковий бізнес. 
Постановка завдання. Відповідно до мети у дослідженні слід окреслити нормативно-правові аспекти франчайзингу, виділити переваги та недоліки франчайзингових систем для франчайзера та франчайзі, відобразити базові критерії для інтеграції та розширення бізнесу у формі франчайзингу, розкрити основні етапи розроблення та впровадження ефективної франчайзингової моделі.

Виклад основного матеріалу. Франчайзинг є ефективним механізмом, що забезпечує комерціалізацію науково-технічних розробок і високоліквідних об'єктів інтелектуальної власності, а також $є$ дієвим способом упровадження інноваційних технологій з метою створення конкурентоспроможної інноваційної економіки.

Франчайзинг - це особлива філософія підприємництва, динамічна система організації бізнесу та етики ділових відносин, $є$ формою взаємодії двох або кількох незалежних суб'єктів господарювання діяльності, заснована на співробітництві та регульована договором, при якій одна організація (франчайзер) надає на платній основі (отримуючи франчайзингові платежі) на певний термін і на обумовленій території іншій організації (підприємцю) або групі організацій (підприємців) - франчайзі - право на використання комплексу виключних прав на об'єкти інтелектуальної власності, а також здійснює технічну, маркетингову й консультаційну підтримку протягом терміну дії договору франчайзингу. За функціональним призначенням та організацією ведення бізнесу виділяють товарний, сервісний, виробничий та змішаний франчайзинг.

Основним нормативним документом, який регулює економічні відносини у франчайзингу в світі, $€$ Кодекс етики франчайзингу. Українське законодавство ототожнює терміни «франчайзинг» та «комерційна концесія», зміст яких відображено як в Цивільному, так і Господарському кодексах України. Широкого розголосу набув проект закону «Про франчайзинг» № 7430, в якому фактично переписані положення глави 76 «Комерційна концесія» Цивільного кодексу України, поєднані із міжнародною термінологією, а також введені недоречні обмеження підприємців, які використовують метод франчайзингу для просування свого бізнесу [1]. Розробники даного законопроекту під франчайзингом розуміють підприємницьку діяльність, хоча це усього лише спосіб просування та збуту товарів і послуг франчайзера із залученням фінансових ресурсів франчайзі.

У країнах Північної Америки та Європи немає безпосереднього регулювання договірних правовідносин між франчайзером та франчайзі, а лише обумовлено перелік питань, відповідно до яких франчайзер зобов'язаний щонайменше за 7 робочих днів до підписання договору франчайзингу розкрити франчайзі інформацію, яка допоможе останньому прийняти рішення щодо укладання або не укладання договору франчайзингу. Тобто франчайзер зобов'язаний подати всю інформацію про себе та своїх посадових осіб, включаючи «судову історію» протягом останніх 5 років, показати фінансову звітність за останній звітний рік, розкрити зміни у фінансовому становищі за останні 3 звітні роки. Франчайзер також зобов'язаний проінформувати про зміст своєї франшизи, вказавши номери реєстраційних свідоцтв на об'єкти права інтелектуальної власності, загальну кількість франшиз та власних торгових точок, що діяли на кінець минулого звітного року. Франчайзі зобов'язані повідомити про розмір усіх своїх капіталовкладень у франшизу, включаючи розмір роялті та паушального внеску, які необхідно буде сплачувати франчайзеру. Франчайзі мають надати перелік контрагентів, 3 якими співпрацює франчайзер і з якими рекомендовано налагодити господарські правовідносини франчайзі [2]. В українському законодавсті не визначено механізм 
переддоговірних та постдоговірних відносин між сторонами стосовно захисту франчайзі, тому що він ризикує отримати та, як показує практика, отримує хибну попередню інформацію про зміст франчайзингового пакета й особливості функціонування майбутнього бізнесу (від порядку прийняття рішень, до підстав дострокового припинення договору).

Лише конкурентоспроможні підприємства можуть розраховувати на організацію бізнесу у формі франчайзингу. Законодавство багатьох країн дозволяє франчайзеру укладати договори франчайзингу лише після спливу щонайменше 3 років самостійної експлуатації франшизи франчайзером. Протягом цього терміну останній має можливість ліквідувати всі слабкі сторони франшизи та розвинути найкращі. У нашому законодавстві відсутня така вимога.

Система франчайзингу, як і будь-яка інша новація на споживчому ринку, може мати певні переваги та й недоліки як для франчайзера, так і для франчайзі. Враховуючи власний досвід минулого у ролі власника франшизи, виділимо переваги та недоліки франчу для обох сторін.

Перевагами франчайзингу для франчайзера є:

- можливість дуже швидкого нарощення бізнесу за рахунок збільшення кількості торгових точок, що супроводжується зростанням обсягів реалізації й розширенням ринків збуту без необхідності залучення значних власних джерел фінансування та завдяки залученим ресурсам франчайзі;

- розширення джерела доходів за рахунок зусиль франчайзі, а також можливого додаткового прибутку від надання в оренду франчайзі нерухомості чи обладнання, проведення проектних та ремонтних робіт для запуску бізнесу;

- зниження витрат на персонал, витрат виробництва, витрат обігу за рахунок того, що франчайзі сам покриває витрати на функціонування підприємства;

- зростання престижу фірми і ії товарного знака, визнання у клієнта збільшення доходу за користування торговою маркою франчайзі;

- можливість накопичувати та удосконалювати управлінський досвід ведення бізнесу по франшизі за рахунок аналізу даних, показників, позитивних та негативних ситуацій у мережі франчайзингу.

До недоліків франчайзингу для франчайзера відносять:

- важке здійснення контролю над франчайзі, оскільки франчайзер не може безпосередньо керувати його співробітниками та бути присутнім у кожній торговій точці одразу або ж мати там свого представника, оплачуючи йому заробітну плату;

- частка прибутку від франчайзингового підприємства менша, ніж від власного бізнесу, однак є гарантованою, оскільки роялті у більшості договорів комерційної концесії зумовлене доходом від реалізації, а не від чистого прибутку франчайзі;

- можливість втрати репутації через недобросовісну, нечесну та неякісну роботу одного з франчайзі, наприклад, продаж останнім продукції, що не відповідає або ж виходить за рамки стандартів мережі чи надання додаткових супутніх послуг, що не передбачаються умовами франчу;

- відсутність впевненості в достовірності фінансових показників результатів діяльності франчайзі та відповідно недотримання прибутку;

- непорозуміння з франчайзі, франчайзер не може замінити його іншим; 
- важко підібрати знаючого основи бізнесу франчайзі, в той же час під час його подальшого навчання франчайзер сам готує собі майбутнього конкурента 3 цього виду діяльності;

- залежність від професійних та особистісних якостей персоналу франчайзера, який у випадку надання непрофесійних, несвоєчасних консультацій франчайзі та його команді з керування, адміністрування та просування бізнесу, може спровокувати своїми діями втрату постійних клієнтів, ринків збуту, отримання збитків і закриття торгових точок у мережі.

Разом із тим можна окреслити переваги франчайзингу для франчайзі:

- отримання готового бізнесу без досвіду його ведення 3 мінімальними капіталовкладеннями та з навчанням від досвідченого франчайзера;

- успішний вихід на ринок під відомою торговою маркою, що не потребує затрат часу та перевитрат ресурсів на становлення та просування бізнесу під власним нікому невідомим брендом;

- постійні консультації та навчання від франчайзера в частині підготовки до відкриття та запуску бізнесу, навчання персоналу, забезпечення ведення технологічного процесу, закупівлі обладнання, облаштування мережі, проведення передпродажних та продажних рекламних акцій, налагодження співпраці 3 постачальниками або ж безпосереднє постачання товарного запасу франчайзером, надання та розроблення асортиментного переліку готової продукції, торгівлі;

- можливість постійного збуту продукції.

До ризиків франчайзингу для франчайзі належать:

- тотальний контроль франчайзером та стандартизованість процесів не дає можливості проявити франчайзі ініціативу, запропонувати нововедення за результатами моніторингу споживчого попиту та проявити самостійність у веденні бізнесу;

- зниження якості продукції чи сировини, несистематичне оновлення асортименту й відсутність компетентних консультацій 3 боку франчайзера при виникненні нетипових проблем у частині адміністрування, виробництва, організації технологічного процесу чи реалізації, зумовлених, наприклад, різною ментальністю споживчого ринку та специфікою регіону, призводить до втрати клієнтів, ринку збуту та отримання франчайзингової системи в частині поставки товарів, обов'язків персоналу, обслуговуванні, уніформи, посадових інструкцій, графіка роботи, ціноутворення, стандартів продукції, товарів чи обслуговування, ведення та складання звітності, реклами, схеми платежів франчайзі, детальна процедура системи контролю за рухом грошових коштів, схеми навчання виробничого та обслуговуючого персоналу, складання бізнес-плану, розроблення порядку укладання франчайзингових договорів;

- приховані витрати, що виникають після оплати паушального внеску франчайзеру, можливість введення в оману та надання франчайзером економічно необгрунтованої та викривленої фінансової моделі функціонування системи бізнесу франчайзингової мережі під час ведення переговорів та підписанням договору комерційної концесії з франчайзі;

- труднощі у підборі компетентного складу кадрів у франчайзі, від професіоналізму якого суттєво залежатиме якість кінцевого продукту.

Побудова успішних франчайзингових моделей повинна складатися з таких етапів:

1. Визначення критеріїв для інтеграції розширення бізнесу у формі франчайзингу, тобто обрати свій бренд, імідж, метод, систему, ноу-хау, торговий знак. 
2. Вибору бізнес-формату, під яким слід розуміти комплексну систему організації бізнесу, яка була розроблена франчайзером та містить певний спосіб оформлення торгового приміщення (транспортного засобу), свій імідж, метод, торговий знак, ноухау, розкручений бренд, певні способи рекламування товарів (послуг), визначений підхід до підбору та навчання персоналу, певний удосконалений спосіб виробництва, оптимізація бюджету тощо. Тобто обрати вид підприємства, на базі якого розробити франшизу, розробити вимоги щодо зовнішнього вигляду, розміру території, приміщення, комунікацій, скласти базовий проект франшизного приміщення 3 оформленням, розташуванням меблів, списком необхідного обладнання, затвердити систему доставки товарних запасів, їх якість та маркування.

3. Встановлення системи відбору та навчання франчайзі шляхом проведення особистих співбесід та анкетування. Розроблення практичних порад з упровадження франшизи 3 системою бізнесу по франшизі, яке зазвичай проводиться на франчайзинговому підприємстві. Комплексне навчання франчайзі проходить до, під час і після відкриття бізнесу по франшизі. Тривалість залежить від характеру бізнесу й триває до 8 тижнів. Навчання проходить не тільки на основі продажу, обслуговування, технологічних процесах, але і за методами управління. В процесі навчання особлива увага приділяється практичним ситуаціям, які можуть виникнути в роботі. Деякі компанії надають координаторів за один-два тижні до відкриття підприємства й на перші дні (тиждень) роботи франчайзі. Якщо виникають проблеми, то робота координатора може бути продовжена до їх вирішення. Подальше навчання проходить у вигляді окремих курсів, семінарів чи он-лайн консультацій 3 різних питань господарської діяльності: бухгалтерському обліку, оподаткуванню, впровадженню нової техніки та інших питань.

4. Процес впровадження й контролю системи франчайзингу проводити на основі базового об'єкта франчайзера. Саме базовий об'єкт буде відправною точкою при визначенні суми фінансових витрат на відкриття бізнесу по франшизі, відпрацюванні технологічних чи виробничих стандартів, правил обслуговування, адміністрування, організації бізнесу, маркетингової політики, логістики, системи обліку та оподаткування, системи контролю за франчайзі тощо.

Перш ніж приступати до бізнесу, франчайзі повинен оцінити свої можливості, зрозуміти, що таке франчайзинговий бізнес і визначити: свої можливості й готовність фінансування франчайзингового бізнесу в потрібному обсязі; чи виправданий ризик втрати власних фінансових коштів; готовність подолання труднощів під час становлення бізнесу, чи буде цікавий даний вид бізнесу протягом тривалого часу. На практиці після проведення особистої співбесіди з франчайзером і утвердження рішення про придбання франшизи франчайзі зобов'язують авансово оплатити паушальний внесок, не розкриваючи при цьому усіх тонкощів функціонування бізнесу по франшизі. Тому, не володіючи інформацією, останній не може об'єктивно оцінити чи ризик втрати власних фінансових коштів буде виправданий, чи ні [5]. Тому при виборі франчайзера франчайзі перед підписанням угоди необхідно отримати вичерпну інформацію про історію розвитку франчайзера, динаміку розвитку франчайзингової мережі, чи є франчайзер членом національної асоціації франчайзингу; чи є компанія франчайзера фінансово стійкою, запросити баланси й фінансові звіти за останні роки; яка система навчання франчайзі; ознайомитися з умовами контракту та зустрітися з працюючими власниками франшиз. 
Висновки. Відображено доцільність створення моделей обов'язкових інструментів розвитку франшизи в частині формування франчайзингового пакета 3 набором інструкцій та описом бізнес-процесів, створення операційної системи ведення бізнесу з використанням ІТ-технологій, побудови єдиних технологічних стандартів, навчальних програм, ведення обліку та складання звітності, системи ціноутворення, маркетингової стратегії просування продукції, визначення рентабельності бізнесу та створення фінансово-економічного обгрунтування кожного формату франшизи, обгрунтування паушального внеску й роялті тощо. Вважаємо за доцільне з метою захисту інтересів та зниження ризиків потенційних франчайзі закріпити на законодавчому рівні обов'язковість розкриття фінансової звітності за три роки франчайзером не пізніше як за тиждень до підписання договору комерційної концесії (фрнашизи), а також встановити дозвіл на відкриття власної франшизи лише після 3 років самостійної успішної експлуатації франшизи франчайзером.

Conclusions. The investigation shows the relevance of constructing models of compulsory franchise development tools in the formation of franchise package with the set of instructions and description of business processes, creating the operating system for business operation using IT technologies, constructing common technological standards, training programs, accounting and reporting, pricing systems, marketing strategy for product promotion, determining business profitability and creating financial and economic substantiation of franchise fee and royalty etc. We think it is reasonable to protect the interests and reduce the risks of potential franchisees by fixing at the legislative level the obligation to disclose financial reporting for three years to the franchiser not later than one week before franchise agreement (franchise) signing, and to determine the franchise authorization of the franchise opening only after 3 years of self-successful franchise franchisee operation.

\section{Список використаної літератури}

1. Карякіна О. Ю. Франчайзинг як правова форма ведення бізнесу (аспект перспективного законодавства). Форум права. 2011. № 2. С. 370-375.

2. Магомедова А. М. Франчайзинг в Україні: проблеми теорії та практики. Формування ринкових відносин в Україні. 2011. № 11. С. 52-56. https://doi.org/10.12927/hcpap.2011.22440

3. Момот Л. В. Розвиток фрайчайзингу в Україні. Наукові праці НУХТ. Економіка і соціальний розвиток. 2014. Том 20. № 5. С. 82-86.

4. Холин Е. С. Франчайзинг: концепция формирования системы, тенденции развития в условиях кризисна. Российское предпринимательство. 2015. Т. 16. № 11. С. 1657-1670.

5. Шевельов Б. Франчайзингові відносини: суть і проблеми розвитку в українському бізнесі. Молодь і ринок. 2012. № 11 (94). С. 148-151.

\section{References}

1. Karyakina O. Y. Franchaisyng yak pravova forma vedennya biznesu (aspect perspektyvnogo zakonodavstva). Forum prava. 2011. № 2. P. 370-375.

2. Magomedova A. M. Franchaisyng v Ukraini: problemy teorii ta praktyky. Formuvannya rynkovyh vidnosyn v Ukraini. 2011. № 11. P. 52-56. https://doi.org/10.12927/hcpap.2011.22440

3. Momot L. V. Rozvytok franchaisyngu v Ukraini. Naukovi praci NUHT. Ekonomika I socialnyi rozvytok. 2014. Tom 20. № 5. P. 82-86.

4. Holin E. S. Franchaisyng: koncepciya formirovaniya sistemy, tendenciyi razvitiya v usloviyah krizisa. Rosiyskoe predprinimatelstvo. 2015. T. 16. № 11. P. 1657-1670.

5. Shevelov B. Franchaisyngovi vidnosyny: sut i problem rozvytku v ukrainskomu biznesi. Molod i rynok. 2012. № 11 (94). P. 148-151. 